Jpn. J. Pharm. Health Care Sci.

一般論文 27(5) 432-441(2001)

\title{
治験におけるインフォームド・コンセントのための 被験者用説明文書の作成とその評価
}

\author{
小池香代 ${ }^{*} \dagger^{1}$ ，近藤勝弘 $\dagger^{1}$ ，江崎哲夫 $\dagger^{1}$ ，樋田治夫 $\dagger^{1}$ ，長谷川信策 $\dagger^{1}$, 松葉和久 $\dagger^{2}$ \\ 名古屋市立大学病院薬侴部市 \\ 名城大学薬学部 $\$^{2}$
}

\section{A Study of Clinical Trial Management by Pharmacists who Complete and Evaluate a Consent form while Providing Informed Consent}

\author{
Kayo Koike ${ }^{*} \dagger^{1}$, Masahiro Kondo $\dagger^{1}$, Tetsuo Esaki $\uparrow^{1}$, Haruo Toida $\uparrow^{1}$, \\ Shinsaku Hasegawa $\pitchfork^{1}$ and Kazuhisa Matsuba $\uparrow^{2}$ \\ The Pharmacy Division, Nagoya City University Hospital $\dagger^{1}$ \\ Faculty of Pharmacy, Meijo University $\dagger^{2}$ \\ $\left[\begin{array}{l}\text { Received April 13, } 2001 \\ \text { Accepted July 12, } 2001\end{array}\right]$
}

In Nagoya City University Hospital, pharmacists evaluated the contents of consent forms in approximately 800 clinical trials from October 1990. The results showed different opinions among sponsors, investigators and pharmacists. These different opinions were related to the observation term, wash out time, comparisons with placebos, the gathering of blood samples for monitoring investigational agents and so on. As a result, it was deemed necessary to completely and objectively revise the consent form.

We therefore conducted two surveys via questionnaires regarding informed consent. Investigators tend to spend time explaining clinical trials to patients. However, this resulted in fewer acceptances. Approximately $85 \%$ of the examinees asked the investigators about the possible effects and adverse reactions of a clinical trial. Our surveys via questionnaires suggest that the concept of informed consent has now become established in Japan.

In order to conduct high quality clinical trials, it is important that completing a consent form is done by a pharmacist who has a good understanding of the pharmaceutical properties of the investigational agent to be used.

Keywords — clinical trial, pharmacist, consent form, placebo, informed consent

緒言

医薬品の臨床試験（治験）におけるインフォームド .
者が自己決定するために必要な情報を効率よく，かつ必 要十分に提供しなければならない。被験者への説明文書 の内容は，被験者の候補者である患者から治験に参加す

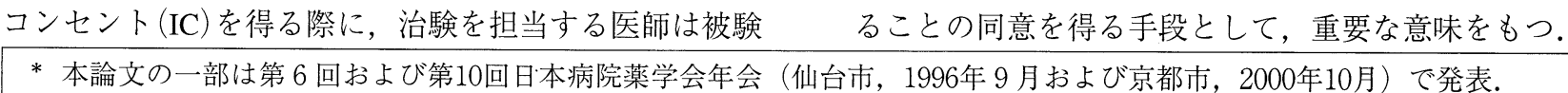

$\dagger^{1}$ 名古屋市瑞穂区瑞穂町字川澄 1 ； 1, Kawasumi, Mizuho-cho, Mizuho-ku, Nagoya-shi, Aichi, 467-8602 Japan

$\dagger^{2}$ 名古屋市天白区八事山150; 150, Yagotoyama, Tenpaku-ku, Nagoya-shi, Aichi, 468-8503 Japan 
「名古屋市立大学病院 (以下, 本院と略す)における医 薬品の臨床試験の実施に闒する基準」の施行に伴い, 薬 剂部が治験事務の庶務を担当して，1991年度から1999年 度の期間に受け付けた治験受託件数（市販後臨床試験を 含む）は791件であった（表 1)．その際，治験依頼者 （以下，依頼者と略す）が用意する IC に利用する被験者 用説明文書（以下，説明文書と略す）に被験者の権利と 自由意思を尊重していないと考えられる文脈, 文言が認 められた。これらの問題について, 治験事務担当の薬剤 師は依頼者および責任医師と協議し, 治験の倫理性, 安 全性, 科学性, 信頼性の確保を目的として説明文書を検 討した。

今後の治験に関与する薬剂師の理念作りの一助とすべ く，われわれが協議した問題点および依頼者と治験担当 医師の治験への考え方の変化について考察を試みた。ま た, 薬剤師が積極的に関与して編集した説明文書の利用 状況と医師による同意取得の傾向についてアンケート調 査し，説明文書の在り方について評価を加えた。

表 1. 名古屋市立大学病院における臨床試験受託件 数の一覧

\begin{tabular}{cccc} 
年度別 & 第 II 相 & 第 III相* & 臨床試験合計件数 \\
\hline 1991 & 86 & 48 & 134 \\
1992 & 94 & 49 & 143 \\
1993 & 77 & 54 & 131 \\
1994 & 74 & 33 & 107 \\
1995 & 46 & 61 & 107 \\
1996 & 29 & 39 & 68 \\
1997 & 23 & 15 & 38 \\
1998 & 7 & 24 & 31 \\
1999 & 13 & 19 & 32 \\
\hline
\end{tabular}

（*：市販後臨床試験を含む）
なお，医薬品の臨床試験の実施の基準に関する省令 (平成 9 年厚生省令第 28 号, 以下 GCP 省令と略す) 施行 後, 本院治験審査委員会委員の構成委員は 10 人（臨床系 教授 4 名, 薬剂部長, 看護部長、医療・臨床試験に関す る専門知識を有しない者として本院事務系職員 2 名およ び医療機関と利害関係を有しない者として本学他学部教 授 2 名）である。会議における審査資料の説明は薬剂部 の治験事務担当薬剂師が行い，補足的に責任医師により 説明される。

\section{方法}

\section{1. 説明文書作成の手順}

治験審査委員会は治験を行うことの適否を審査するに あたり, IC 取得に利用する説明文書の記載内容および 表現方法の妥当性について審議する. 薬郕部治験事務担 当の薬剤師は治験実施計画書および治験薬概要書等の申 請資料に基づき，会議説明資料となる「治験の要約（A 4 判 2 頁)」を作成する。この資料作成過程において, 依頼者には(1)治験薬開発の経緯（海外での開発状況を含 む)，(2)前相までの成績, (3)治験への参加基準, (4)治験 除外基準, (5)試験方法, 6治験実施上の注意, (7)治験成 績の評価の方法, 8被験者が受ける臨床検査の種類・時 期の 8 項目について確認を行った。 また, 医師には(1)具 体的な被験者選択, (2)治験実施上の注意事項, (3)被験者 が受ける検査の種類・時期, (4)被験者が採取される検体 の種類, (5)同意取得の方法の 5 項目について確認を行っ た。

上記資料確認とともに, 説明文書 (表 2)について, 薬 剂師と依頼者と責任医師との間で15の説明必須項目 (省 令施行前は 6 項目）について意見交換を行い，意見が異 なる場合はその「理由書」を会議に審議資料として提出 した ${ }^{1)}$. 本院の説明文書は, 同意書と一連のものとした

表 2. 被験者用説明文書の必須項目の比較

$\diamond 1994$ 年に书ける説明項目 (GCP 省令施行前)

1.治験の目的および方法
2.予想される効果および副作用
3.他の治療法の有無およびその内容
4.治験の参加に同意した場合であっても随時これを撤回できること
5.治験の参加に同意しない場合であっても不利益はうけないこと
6.被験者の人権保護に関して必要な事項

6.被験者の人権保媵に関して必要な事項

$\diamond 1998$ 年における説明項目（GCP 省令施行後）

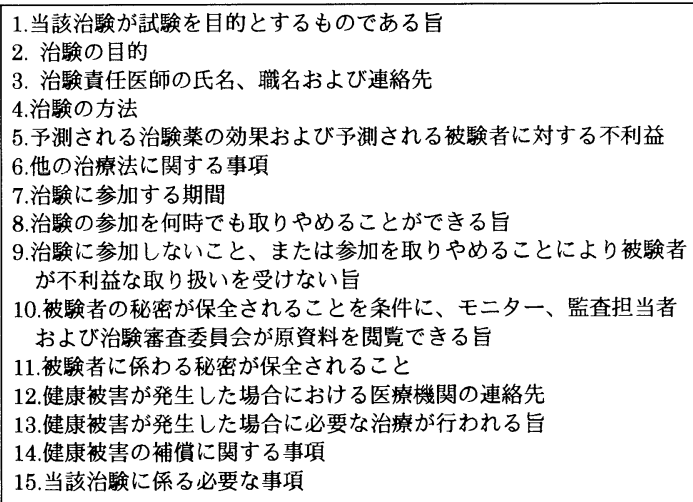


書式（3 枚複写）で作成している.

\section{2. 同意取得状況のアンケート調查}

医師を対象に説明文書の利用状況に関するアンケート 調査を1995年12月と2000年 4 月の 2 回に実施した。1995 年当時の治験参加同意取得は一般に口頭で行うことも認 められていたが，本院では文書により同意取得(表 3 )す ることと，説明文書 1 部を被験者に手渡すことを原則と していた。第 1 回目のアンケート調查は本院の治験を担 当する医師60人 (14診療科) を対象とし(責任医師は講座 責任者の教授であるため除外)，表 4 に示す設問内容を 無記名で行った。第 2 回目はGCP省令施行後に実施 し，アンケート調査は責任医師31人㧍よび分担医師49人 の合計 80 人(15診療科) を対象に行った(表 5 )。第 2 回 調査の設問内容(表 6 ) には，GCP 省令施行後の本院に 扮ける変更点，すなわち(1)責任医師，薬剂師，依頼者に よる三者協議，(2)段階的な説明による同意取得，(3)他施

表 3. 名古屋市立大学病院に扔ける同意取得状況の 一覧

年度別文書同意の被験者数 口頭同意の被験者数

$\begin{array}{rrr}1991 & 66 & 9 \\ 1992 & 333 & 24 \\ 1993 & 358 & 1 \\ 1994 & 409 & 1 \\ 1995 & 309 & 0 \\ 1996 & 376 & 0 \\ 1997 & 233 & 0 \\ 1998 & 140 & 0 \\ 1999 & 99 & 0\end{array}$

設での重篤な有害事象に対する責任医師の意見提出につ いて，新たに追加した。

アンケートの回収率は，1995年の調査では $80 \% ， 2000$ 年の調査では $59 \%$ であった.

な㧍，本院では GCP 省令施行後から，治験担当医師 が小冊子『「くすり」と「治験」』を用いた治験一般に関 する説明を行い，さらに説明文書（詳細な情報提供のた めの補足説明文書がある場合は 3 段階の説明）を用いて 説明を行ったうえで，同意取得を行う（本院には治験 コーデイネーターは配置されていない).

\section{結果}

\section{1.「説明文書」における表現の協議(表 7 )}

1 ）薬効の表現

GCP 省令施行前の1994年における依頼者が用意した 説明文書で依頼者と薬剂師の間で特に意見が相違した表 現は，「新しい㧍薬」「効果が認められている」などで あった。これらはすでに「新しい治療薬として」，また 「薬効が確認された」という意味を表現する言葉であ る。このような表現は依頼者との協議で，「開発途中の 薬効を調查する物質」であることを考慮し，「開発中の 薬」「効果が期待されている」という表現へ変更された。

2 ）副作用の表現

副作用の表現では，治験中にもかかわらず，「わずか な副作用」とか「副作用の危険性のない」という表現が とられた場合は，形容詞・副詞の表現を避けて，これま でに観察された副作用の発生頻度を「数値で表現する」 ように薬剤師から変更を求めた ${ }^{3)}$. 副作用の程度・頻度 の表現は，GCP施行前の説明文書 A 4 判 1 頁から，施

表 4.1995年の設問＼cjkstart治験における患者への同意取 得に関するアンケート

1）貴方は、治験で患者の同意を得るのに「患者用説明文書」を使いましたか?

2）「患者用説明文書」を利用する上で困った経験がありましたか?

3）同意取得に当たり、「患者用説明文書」の取扱いで多いのは次のどれですか?

(1)「患者用説明文書」で説明する。患者へは渡さない。

(2)「患者用説明文書」で説明する。患者へ渡す。

(3)「患者用説明文書」は利用しない。

4）治験をお願いする説明の時に、患者の質問で多いのはどれですか？

(1)目的および方法に関すること

(2)効果および副作用に関すること

(3)その他（具体的に

5）治験で、患者から「考える時間がほしい」と言われたことがありますか？

6）患者へ治験をお願いする説明に要する時間は、平均してどれ程ですか?

(1)10分以内 (2)10分から30分程度 (3)30分以上

7）治験をお願いする説明で、治験への参加を断られた経験はありますか?

8）「患者用説明文書」は、保存していますか?

9）説明文書および同意取得に関して、ご自由に意見をお書きください。 
行後は最大 10 頁まで増加し, 記載される傾向へ移ること が認められた。

3 ) 観察期間およびプラセボの表現

GCP 省令施行前には，依頼者が用意した説明文書に は「(無治療期間となる) 観察期間を設定すること」, 「プラセボ対照群を設定すること」，さらに「プラセボに

表 5.アンケートを配布した診療科別医師数

\begin{tabular}{lrc}
\multicolumn{1}{c}{ 診療科 } & 1995年 & 2000年 \\
\hline 内科 $(1,2,3)$ & 21 & 41 \\
外科 $(1,2)$ & 6 & 2 \\
整形外科 & 6 & 7 \\
産科婦人科 & 7 & 2 \\
小児科 & 5 & 5 \\
眼科 & 0 & 3 \\
耳鼻咽喉科 & 3 & 2 \\
皮膚科 & 0 & 2 \\
泌尿器科 & 3 & 5 \\
精神科 & 3 & 4 \\
放射線科 & 2 & 0 \\
麻酔科 & 2 & 4 \\
脳神経外科 & 2 & 3 \\
\hline 医師数合計 & 60 & 80 \\
\hline
\end{tabular}

代わる有効以下の低用量群を設定すること」に対する説 明がまったくなされていなかった。また，GCP省令施 行後には，単に「偽薬」「プラセボを服用」と記載され ていたとしても，「プラセボとは有効成分を含まないも ので，十分な効果が期待できないもの」であるように， 被験者がより具体的にプラセボを理解できるような説明 がなく, 変更を求める必要性を認める事例がほとんどで あった．特にプラセボの解釈を不明瞭とする有効量以下 の低用量群をプラセボ対照群とする考え方では，1994年 度に 3 件（1 件は実施計画書に未記載)，1998年度に 1 件を協議した。この他, 盲検性確保のためのダミー用プ ラセボ使用や, 高血圧症や排尿困難症を対象とする場合 の治験薬投与前の観察期用プラセボ使用についても, 「有効成分を合まないもの」を使用することが理解でき るような説明を加える必要性があることについても協議 した。

4 ) 侵襲的行為の説明

「体内動態試験に招ける被験者からの検体採取の必要 性，検体の種類および採取時期 ·回数」については, GCP 省令施行前にはまったく説明されていなかった。 GCP 省令施行後にも説明がないか，あるいは「採血し ます」というように単に用語の記載に留まった場合，内

表 6. 2000年の設問内容

治験に関する1998年 4 月以降の同意取得状況アンケート

1 ）治験で患者の同意を得るのに「くすりと治験」の小冊子で説明した後、治験審查

委員会で承認された「患者用説明文書」を使いましたか?

2 ）「患者用説明文書」を利用する上で困った経験がありましたか?

3 ) 同意取得に当たり、「患者用説明文書」の取扱いで多いのは次のどれですか?

(1)「患者用説明文書」で説明し、その日のうちに同意取得する。

(2)「患者用説明文書」で説明し、考える時間を与えてから後日、同意取得する。 (3)その他（具体的に

4) 治験をお願いする説明の時に、患者からの質問で多いのはどれですか?

(1)目的および方法に関すること

(2)効果および副作用に関すること

(3)その他（具体的に

5 ) 患者へ治験をお願いする説明に要する時間は、平均してどれ程ですか?

(1)10分以内 (210分加530分程度 (3)30 60分 (4)60分以上

6 ）いったん治験を同意した患者から「同意を撤回したい」と言われたことがありますか？

7 ）治験をお願いした患者の中で、同意を得られなかった患者の割合はどれくらいですか?

8 ）薬剤師が治験協力者となる場合、どのような業務を期待しますか? (複数回答可)

(1)医師が同意取得を行う前に、治験について一般的な説明を行う。

(2医師が同意取得した後に、治験実施について補足説明を行う。

(3)治験について患者の質問・相談に対して情報提供等を行う。

上記以外にも具体的に：

9 ) 医師、薬剂師、治験依頼者の 3 者による治験審査委員会開催前ヒヤリングをどう思いますか?

10）安全性情報に対する治験責任医師の意見を治験審査委員会に提出することをどう思います か?

11)治験に関して、ご自由に意見をお書きください。 
表 7. 説明文書に使われていた表現における治験依頼者・治験責任医師と薬 剂師との認識の差

\begin{tabular}{|c|c|c|}
\hline 検討を必要とした内容 & 依頼者・医師側の表現 & 病院側薬剂師の求めた表現 \\
\hline 客観性に欠ける表現の & 新しいお薬 & 開発中の薬 \\
\hline \multirow[t]{3}{*}{ 排除 } & 優れた効果が認められている & 効果が期待されている \\
\hline & わずかな副作用 & 下痢が $5 \%$ （60 人中 3 人） \\
\hline & 高用量と低用量 & $80 \mathrm{mg}$ 群と $40 \mathrm{mg}$ 群 \\
\hline \multirow{4}{*}{$\begin{array}{l}\text { 観察期を設定する場合 } \\
\text { （wash out 期間を含む） }\end{array}$} & 説明の記載なし & 服用中の治療薬が中断される \\
\hline & & 治療の開始が遅れる \\
\hline & & 無治療となる期間ができる \\
\hline & & 観察期用プラセボを服用する \\
\hline \multirow[t]{4}{*}{ ブラセボ対照群の場合 } & 説明の記載なし & 有効成分を含まないので十分な効果 \\
\hline & 効果が少ないお薬 & が期待できないもの \\
\hline & 偽薬 & \\
\hline & プラセボ & \\
\hline \multirow{2}{*}{$\begin{array}{l}\text { 有効量以下の低用量群 } \\
\text { の場合 }\end{array}$} & 高用量か低用量のうち & 60mg あるいは 6mg（十分な効果が \\
\hline & いずれかの量を服用 & 期待できない量）を服用 \\
\hline \multirow[t]{7}{*}{ 血中濃度測定の場合 } & 説明の記載なし & 検体採取の必要性、測定時期 - 回数の説明 \\
\hline & 採血します & 治療に直接関係しませんが、あなたに投与 \\
\hline & & された治験薬が血液中にどのくらいある \\
\hline & & のかを調べさせていただくために、服用 \\
\hline & & 後く日に口回、採血させていただきます \\
\hline & & 免疫反応の検査を行わせていただきますの \\
\hline & & で 3ml を余分に採血します \\
\hline 検体採取の場合 & 説明の記載なし & $\begin{array}{l}\text { 測定の必要性、測定時期・回数の説明 } \\
\text { 治験楽を } 1 \text { 回飲んだ後、手術で取り除か } \\
\text { れる } \triangle \triangle \text { 組織の一部をいただきます }\end{array}$ \\
\hline
\end{tabular}

視鏡検査など治験に伴う侵襲行為を行う必要性の是非 や，痛みや危険を伴う検査を受ける被験者側の利益，時 期・回数を明示しない事例についても協議した。

5 ）協議を必要とした頻度

「不適切な表現」や，「被験者の理解が困難」と考元ら れる文脈・文言は，依頼者が用意したすべての説明文書 に認められた．特に，各アンケート調査時の前年（GCP 省令施行後は 2 年分）について「説明の記載がない」, あるいは「十分な説明をしていない文章がある」として 検討された説明文書は，1994年度総受託件数107件中 48.6\%であった. 1998年および1999年度の 2 年間の総受 託件数63件では71.4\%であった．検討を要した主な項目 には，「観察期間の設定」と「プラセボ対照群の設定」 があり，順に，GCP省令施行前の30.8\%と19.6\%から， GCP 施行後の57.1\%と31.7\%に増加していた（表 8 ).

この他，GCP 省令施行後，依頼者と薬剂師の二者協 議から責任医師を加えた三者協議に変更したことによ り，上記 1 ）～4）以外にも依頼者と協議・確認された 件数が， 2 年間の受託件数のうち $25 \%$ (16/63件) あっ た。依頼者へ問い合わせた事例としては，wash out 後の 被験者組み入れの適否や，副腎ステロイド製剂使用制限
の程度など被験者の選択に関する事項, 治験薬の安全性 情報の評価, 被験者への支払に関する事項など 5 件 （８％）であった。また, 実施計画書の記載を詳しく確 認する必要性が認められたのは，国外で実施された用 法・用量と同一に設定されたブリッジング試験に関する 事項 7 件，プラセボ群未評価のまま実薬投与長期試験へ の移行が計画されていた試験に関する事項 1 件などの 11 件 $(17 \%)$ であった(表 9 ).これらは説明文書の書き換え を伴うものではないが，治験審査委員会の検討資料とし て作成された。

\section{2. アンケート結果からみた説明文書の利用状況}

1995年第 1 回アンケート調査および2000年第 2 回アン ケート調査の結果から，治験審査委員会事務担当の薬剤 師が協議・調整・編集して治験審査委員会が承認した同 意取得に利用される説明文書の医師による利用状況は次 の通りであった。

1) 説明文書の利用状況

1995年の調査では $12 \%$ （6/48人）が「説明文書（A 4 判 1 頁以内)」を利用していないとの回答であった。こ の理由は「口頭で説明するので必要としない」というも 
表 8. 治験依頼者・治験責任医師が用意した説明文 書について検討を要した項目と割合

\begin{tabular}{|c|c|c|c|c|}
\hline \multirow{2}{*}{$\frac{\text { 検討を要した項目 }}{\text { 覾察期間 }}$} & \multicolumn{2}{|c|}{1994 年 } & \multicolumn{2}{|c|}{$1998 \sim 1999$ 年 } \\
\hline & 33 件 & $(30.8 \%)$ & 63 件 & $(57.1 \%)$ \\
\hline ユプラセボ群* との比较 & 21 件 & $(19.6 \%)$ & 20 件 & $(31.7 \%)$ \\
\hline 曼垶行為 & 14 件 & $(13.1 \%)$ & 7 件 & $(11.1 \%)$ \\
\hline 延べ合計件数 & 68 件 & & 63 件 & \\
\hline $\begin{array}{l}\text { 緿治験受託件数 } \\
\text { 総治験数に対する割合 }\end{array}$ & & $\begin{array}{l}07 \text { 件 } \\
52 \text { 件 (48.6\%) }\end{array}$ & & $\begin{array}{l}63 \text { 件 } \\
45 \text { 件 }(71.4 \%)\end{array}$ \\
\hline
\end{tabular}

表 9. GCP 省令施行後に治験依頼者・治験責任医師と薬剤師との協議で 確認を必要とした項目と受託件数

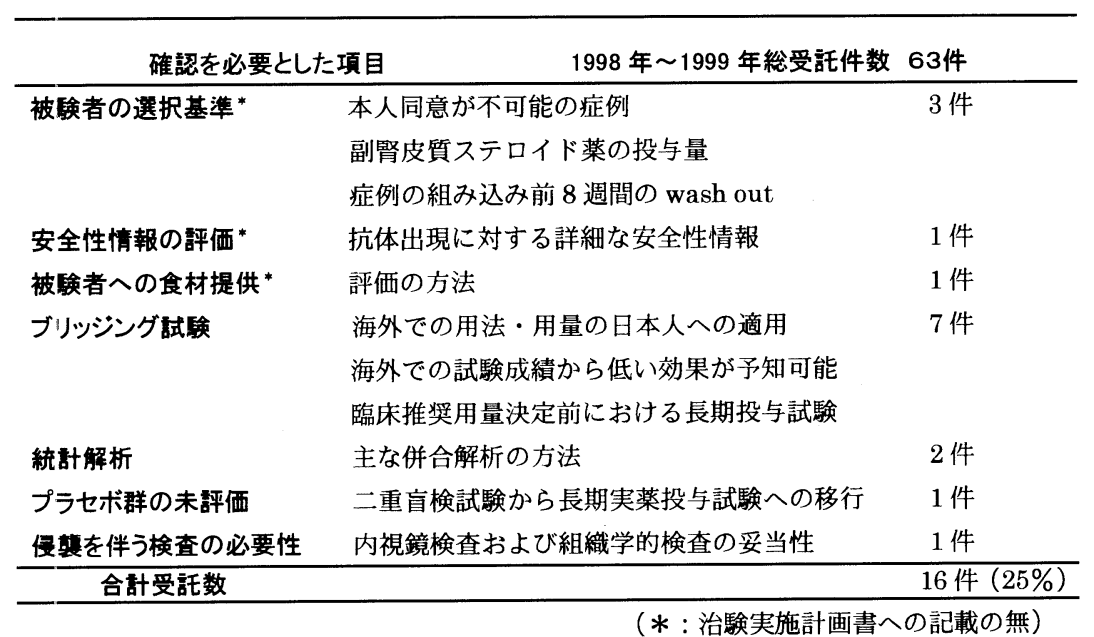

のであった。2000年には説明文書（A 4 判 3 〜 10頁）の 写しを交付することは義務化されていたがその中 で，72\%(34/47人）が段階的な説明による同意取得を 行っていた。 小冊子2)を利用して「治験」とは何かを説 明してから同意取得の説明を行うことについては，「口 頭説明で十分」あるいは「内容が理解しにくい」との理 由から $19 \%$ （9/47人）の医師が必要なしという回答で あった。

一方，「説明文書の利用で困った経験があるか」の設 問には，1995年には75\% (36/48人)，2000年には77\% （36/47人）が問題なしとの回答であった。困った経験と して，1995年には「患者を実験対象にするという印象が 強い」，「副作用が強調されている」，「外来患者に説明す るのに時間がかかりすぎる」との意見であり，両年とも には「患者にその場で理解させるには量が多い」という 意見であった。

1995年の調査では，「説明文書で説明するが，文書は 患者に渡さない」との回答が40\%（19/48人)，「説明後 に患者に渡す」が $48 \%$ (23/48人),「説明文書は利用し
ない」と回答した医師は $12 \%$ （6/48人）の割合であっ た。患者へ説明した後，「考える時間がほしいと言われ たことがある」と回答した医師が $54 \%$ (25/48人) い た。 その時, 患者の挙げた理由は「家族と相談して決め たい」，「説明文書をよく読んで返事したい」などであっ た。一方，2000年には，「考える時間を与えて後日に同 意取得する」との回答は $49 \%$ （23/47人）であり，説明 文書を利用して説明し，「その日のうちに同意取得す る」医師の $40 \%$ （19/47人）を上回っていた(図 1 ).

2 ）説明に要した時間と被験者の不同意，質問

治験への参加依頼に要する時間は，1995年の調査では 医師の $58 \%$ （28/48人）が「10～30分程度」の時間を説 明にかけていた。60分以上の長時間の説明を行うという 医師も $2 \%$ （1/48人）いた. 2000 年の調査でも同様な 傾向であったが，「30分以上」が17\%から26\%へと増加 するなど，一般に説明時間は長くなる傾向にあった。

しかし，治験への参加を断られた経験がない医師は 1995年の調査では約33\%であったが，2000年では約20\% に減少していた。 


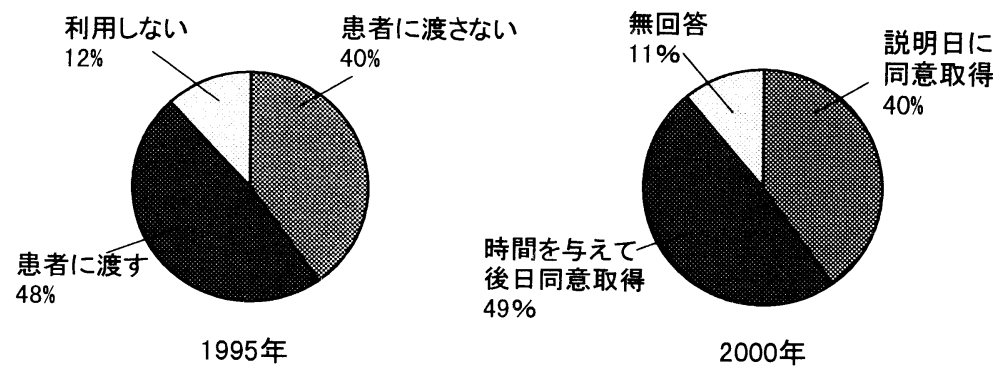

図 1. 説明文書の取り扱い方法
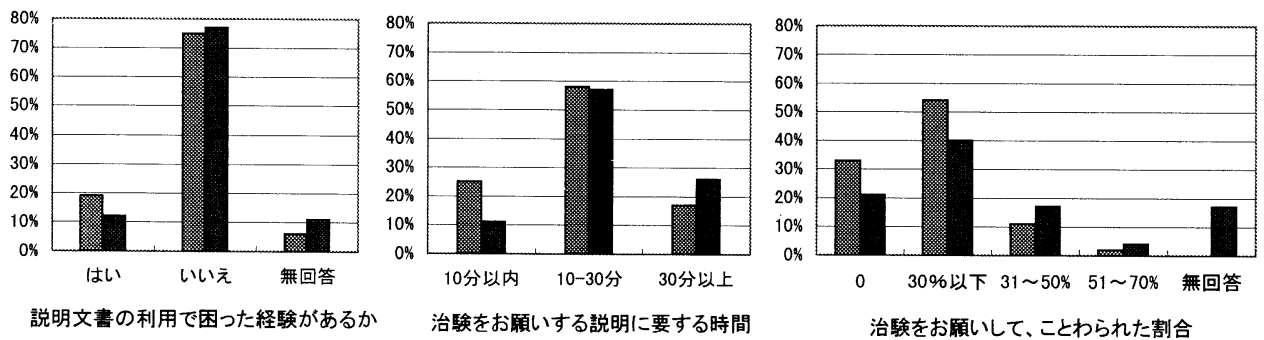

図 2. 同意取得状況の比較

1995年,

2000年）

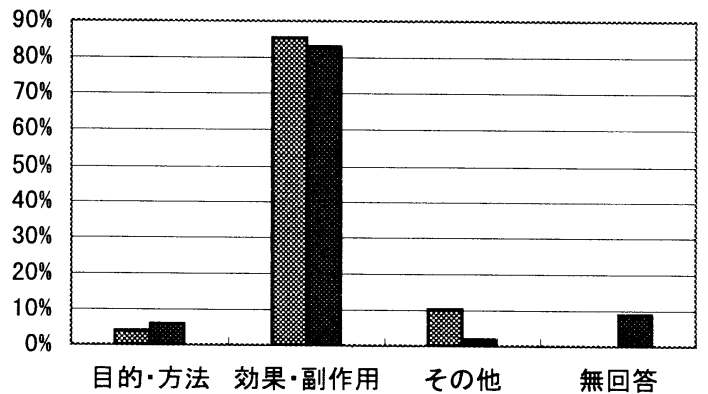

図 3. 被験者からの質問（圈 1995年，

2000年

また，「同意を撤回したいと言われた経験」がある医 師は $23 \%$ （11/47人）であり, 同意撤回の理由は「有効 でも治験終了後は使用できないため」，「手続きなどで長 く時間がかかるので仕事に影響するため」，「副作用が心 配になった」，「家族に反対された」，「観察期間に症状が 悪化したため」などであった。治験への参加に同意を得 られにくい傾向や同意取得後にも断られることがあるこ とが明らかとなった（図2）。

被験者からの質問の大部分は「効果・副作用」であ り，1995年，2000年ともに，それぞれ85\%（41/48人)， 83\%（39/47人）であった。その他の質問として，1995 年は「なぜ自分が選ばれたか」，「プラセボ群になった時 の心配」であり，2000年は「有効であっても治験終了後 に治験薬の提供はないのか」などであった(図３）.

3 ）説明文書作成への薬剂師関与の是非
設問 9 の治験事務担当の薬剤師が説明文書を整備・編 集する最終調整として行う依頼者や責任医師との「ヒア リングに対する意見」では，「医師が治験内容を認識し て責任感が向上する」，「薬剤師の意見に考えさせられる ことがあり医師の独善を防ぐことができる」，「三者間の 意思統一が図れる」などの理由から，77\%（36/47人） の医師がそのあり方を肯定していた。しかし，設問 8 の 「薬郕師が治験協力者となることへの期待」に関して は，「患者からの治験に関わる質問・相談に対して情報 提供を行う」，「医師が同意取得した後に補足説明を行 う」ということについて，それぞれ44\%（28件/複数回 答63），32\%（20件）と消極的意見となっていた.

2000年の調査では，情報提供以外による治験実施計画 の逸脱回避や被験者ケアなどの関与への希望はなかっ た。

$4 ）$ 治験担当医師の治験全般についての意見

アンケートに記載された治験担当医師の自由な意見を 記載する欄では，1995年時には副作用を記載することへ の賛否の異なる意見が，また，2000年には治験体制の整 備を求める意見が寄せられた(表10).

\section{考察}

\section{1. 薬剤師の貢献}

薬剂師による事前審査・依頼者とのヒアリングが重要 であるということの報告は多い4-9. われわれの調査研 究でもこれらの過程の重要性を証明した。説明文書の表 
表 10．治験に関するアンケートにおける治験責任

医師および治験分担医師の意見

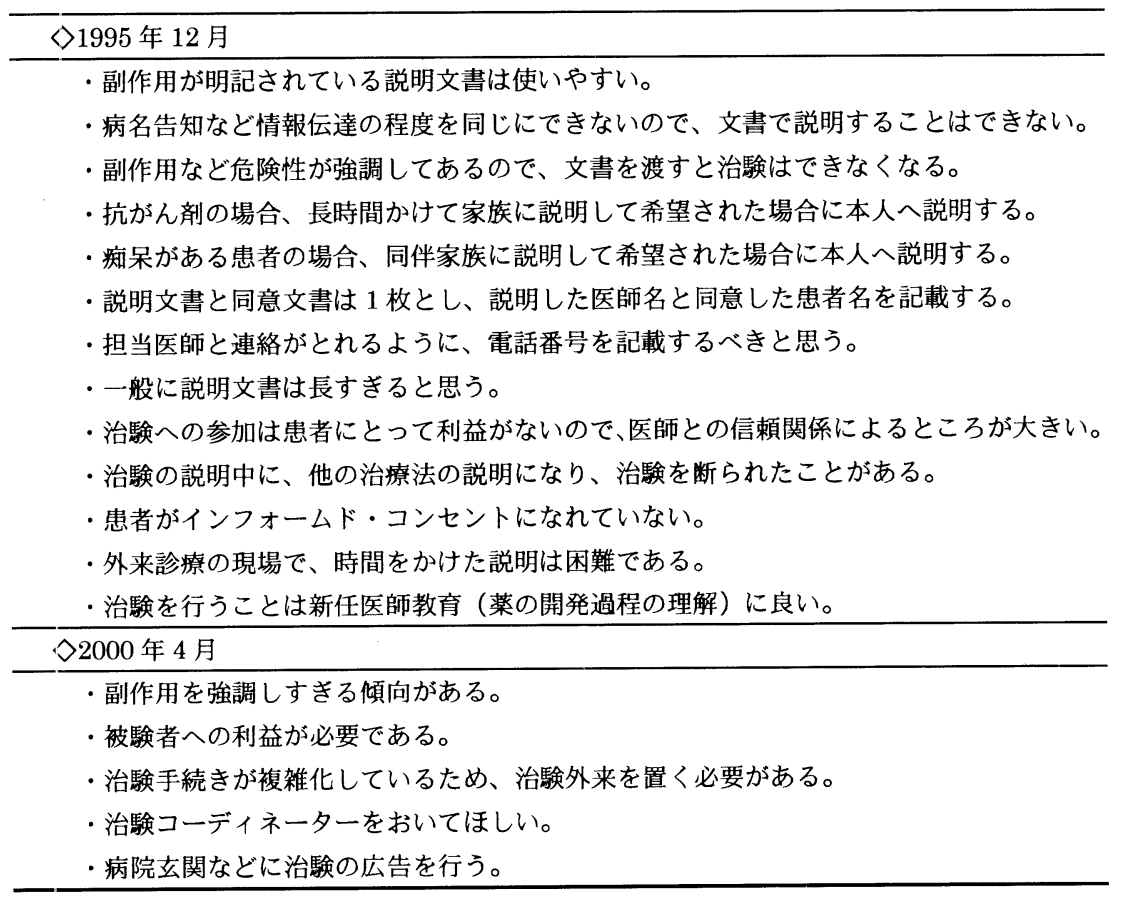

現の検討における，依頼者，責任医師，薬剂師の三者協 議における考え方の基準は，「客観性に欠ける表現を排 除して妥当なものにする」ことであった。薬剤師から積 極的に被験者への配慮を求めた事例の全受託件数に対す る割合は GCP 省令施行前の $48.6 \%$ から, 施行後は $71.4 \%$ に増加した(表 8)。これは，「観察期間（wash out 期間 を含む), プラセボ対照群, 有効量以下の低用量群, 血 中濃度測定, 組織内濃度測定, 内視鏡検査」など, いわ ゆる「被験者が不利益を受ける可能性についての説明」 が増加してきたことが原因として挙げられる。これらの 説明を被験者が理解できるように書き改めることについ て意見交換することは，依頼者と責任医師に改めて問題 点を注目させ，治験への認識を向上させる方向へ働いた 点で効果があったと考えられる(表 7 )。 また, 三者ヒア リングでは，治験薬および実施計画を詳細に理解して三 者間の認識の差を埋める形で説明文書を作成するため, 新薬開発について体系的に学び, 臨床試験ガイドライン について精通する薬剤師は適任であり ${ }^{4)}$, その役割は効 果的であった。そして，これは治験審査委員会の審議を 効率的に行うための事前ヒアリングとしての意味を持っ た。医薬品開発の世界基準が日本に定着するに従い，表 7 に揭げたような被験者への配慮を十分に検討する必要 性のある，より科学的な治験成績を得るための治験デザ インが重要視される. 今後, 治験薬の評価とともに, 説 明文書の検討の意義はより重要性を増すといえる。
依頼者や責任医師には治験と治療を混同している者が 多いため，「被験者の候補者である患者が治験参加を自 己決定するために必要十分な情報を提供する」，「治験は 研究を伴うものであるということを理解させたうえで治 験参加への同意を得る」という認識が低いことが考えら れる。このような考え方は，「治験を成功させたい」, 「治験に参加させたい」というそれぞれの立場をバイア スがかかったものとして理解すべきであろう。さらに， 末廣ら ${ }^{5)}$ は「依頼者は最終的には説明文書は責任医師が 作成するものと考えているため十分なものではないこ と」,「依頼者は説明文書作成上の最大の問題点として は，情報量が多すぎることであると考えていること」を 報告している。このような観点から，提出されたままの 説明文書では被験者に十分な情報提供ができない.この 傾向を是正する立場として, 薬剤師は依頼者である医薬 品開発担当者と治験を担当する医師の双方から情報を得 やすい立場を利用して，第三者としての視点から被験者 の権利を考えることができる。薬荗師が，被験者に対し て実質的に重要な意味を持つ説明文書の作成に関与する ことの意義は大きいといえる。

\section{2. プラセボに対する考え方}

特にプラセボに対する認識に，薬郕師の第三者として の考え方が反映される.

今回の調査で,「有効量以下の低用量群をプラセボ群 
とする」と依頼者が考えた 4 件については，提出された 説明文書には「高用量か低用量のうちいずれかの量を服 用します」と記載されていた。低用量群では期待される 有効性が少ないことが予知できるのに，その結果を説明 しない表現ではプラセボの説明とはならないとして協議 の対象とされた，協議の過程で，依頼者からは「被験者 に十分説明すると治験参加への同意が得られないという 危惧」,「医師が説明する際の困難な状況を避けたい工夫 として責任医師に配虑する考え方」が説明された。ま た，責任医師には「治療が行えないことを説明するため には患者との信頼関係が不可欠」との消極的認識から， 「説明を避けることはできない」と積極的に臨床試験を 認識できるように変化が認められた。実薬に対するプラ セボ対照比較試験でありながら，「低用量群」にプラセ ボとしての役割を担わせて有効性の低い群として説明し ようとすること，また，用量非依存性の過敏反応の危険 性を持つことになるなど，プラセボの代わりに低用量群 を設定する比較臨床試験は今後考えるべき課題である. 光石 ${ }^{10)}$ は, 専門家としての医師の意識には薬は効くも のとの思い込みがあり，プラセボ対照は非倫理的との考 えが強いこと，臨床試験を治療とみなす考えがあること を指摘した上で，プラセボ対照臨床試験では生命権・平 等権など被験者の人権の基層をなす権利を保障した上で のICでなければならないと主張している。つまり，プ ラセボ対照群の被験者に対して IC は当然であるが，そ れ以前の問題として標準的治療を受けられないことで平 等の原則に反しないかの考えなどから，公正な審査を求 めている。これは治験審查委員会の責務の重大性を指摘 するものであるが，治験デザインを治験審査委員会が承 認しないことは当該施設での治験実施を否定することに 繋がるという問題が生じるため，被験者に対しては治験 の本質を理解できるような説明や，被験者が質問しやす い環境整備が重要である，治験に対する立場の違いによ る認識の相違を考えれば，薬剂師が中立的な立場で説明 文書の作成に積極的に参加することは意義があり，かつ 治験審查委員会の質的向上に寄与することができる.

また，薬剤師が説明文書の作成に参画することによ り，治験参加を考える上で必要な情報を，被験者の候補 者が理解しやすい文脈・表現の文書として手渡すことが できた。そして，説明文書作成の過程において，依頼 者・責任医師・薬剤師との間における治験への認識の共 有化が，治験の質の向上に大きく貢献することが示唆さ れた。

\section{IC における説明文書の利用状況とその在り方}

ICにおける説明文書の利用状況は，1995年には医師
の約10\%が副作用の記載された説明文書は利用できない という意見であったが，2000年には有害作用の説明が 入った文書が必ず被験者へ交付されるようになった。こ のことは，1997年の GCP 省令第51条〜第55条に扔ける 被験者の人権保護に関する規定の影響が大きいといえ る。

この他にも，1995年の国際調和会議 GCP(案)の公表 後に厚生省がん研究助成金指定研究「固形がんの集学的 治療の研究」班に扔いて, がん臨床研究のインフォーム ド・コンセントの指針が改訂され，ICの前提にはすべ ての情報開示（治療関連死も含む）があり，患者が医師 に臨床試験を行うことを許可することが ICであり，十 分な説明と文書同意を必須条件としたことが，がん告知 を普及させたと考えられる111.

また，ソリブジン事件（1993年）後の自分の服用薬へ の関心の高まりやエイズ薬害問題が誘引となって医療に 扮ける情報開示が社会的に浸透した結果，説明文書への 副作用明記を医師が受け入れるように変化したという背 景要因も考えられる。

2 回の調査とも, 治験参加依頼に要する時間は, 約 60\%の医師が10３0分と答えていた．1995年には10分以 内とした医師が約 $1 / 4$ であったが，2000年には30分以 上が約 $1 / 4$ となったことからみて，少数ではあるが, より長い時間を説明に費やす医師がいることは今後さら に好ましい傾向である（図 2 ）。また，同意を得る手順 として, 段階的な説明を行う医師が約 $3 / 4$, 被験者が 望む「考える時間がほしい」に対して1日以上の余裕を 持たせて行う医師が約 $1 / 2$ いたことは，医師が患者の 声に耳を傾け，真に治験を理解できるまで説明しょうと 努力していることを示すものであり，同意の自発性を重 要視する ICが医療現場で着実に定着しつつある事実と いえる。そして，治験参加を断る患者の増加は，説明文 書が治験に参加する者が意思を決定するための情報とし ての役割を担っていることを裏付けている.

被験者からの約 $85 \%$ の質問が「効果と副作用」である ことは，被験者の候補者である患者の関心が「治療」に あることを示唆し，また，治験の具体的な方法が理解さ れた結果とも考えられる。その他の質問として，「自分 がプラセボ群になった場合の心配」をしていることは, この危惧に対する理解を関係者はより考慮すべきであ る.

説明文書は単に同意書に署名することを促すために利 用するのではなく，被験者の候補者が繰り返し読んで内 容を実質的に理解し，自己決定するための情報として手 渡すことが重要である。特に不利益の項に記載される有 害事象については，副作用の早期発見に役立つ情報とし 
て活用されるべきである。

治験における説明文書は, 被験者の医療への信頼感と

満足感を高め, 治験の質的向上の一助として重要な役割 を担うものである.

今回の調査研究では, 説明文書がコミュニケーション を図るための情報源として，また治験審査委員会および 臨床試験実施における倫理性, 安全性, 科学性, 信頼性 の確保に有用であることを確認することができた，薬剤 師が依頼者, 責任医師とは異なる視点から, 治験におけ る説明文書作成に参画することが意義あることを明らか にした。

\section{引用文献}

1）小池香代, シンポジウム新 GCP の進め方一薬剂 部のできること，日本病院会雑誌，46，896-902 (1999).

2）日本製薬工業協会企画・編集，“「くすり」と「治 験」” (平成10年10月以降, 改訂版).

3）小池香代, 江崎哲夫, 桶田治夫, 松葉和久, “第 6 回日本病院薬学会年会講演要旨集”, 1996, pp. 508 -509 .

4）尾崎淳子, 乾賢一, 治験審査委員会の体制作り, 月刊薬事, 40, 2245-2248(1998).
5）末廣勉, 藤戸博, 森昌斗, 治験被験者用説明文書 の問題点の検討，医薬ジャーナル，34, 117-123 (1998).

6）二神幸次郎，定金典明，川上英治，荒木博陽，川 㟝博己, 五味田裕, 治験薬管理の実際, 日本病院 薬剂師会雑誌，34，879-882(1998).

7）川上英治，二神幸次郎，定金典明，西原茂樹，荒 木博陽, 川㟝博己, 五味田裕, 治験薬の一元管 理, 病院薬学, 25, 69-75(1999).

8）杉山正, 安田浩二, 後藤千寿, 片桐義博, 治験実 施における薬剤師の係わりとその重要性に関する 検討，臨床薬理，30，675-679(1999).

9）石塚良子, 深津祥央, 丸山志穂子, 中桐真樹子, 尾崎淳子, 石津雅弘, 乾賢一, 篠山重威, 京都大 学病院における適正な治験実施のための取り組 み, 医療薬学, 27, 57-62(2001).

10）石光忠敬, プラシーボ対照と被験者・患者の人 権，臨床精神薬理，2，137-144(1999).

11）下山正徳他, 厚生省がん研究助成金指定研究「固 形がんの集学的治療の研究」班における臨床試験 計画の作成と実施, 並びに結果の統計解析とその 評価に関するガイドライン（改訂第 3 版）第I部 がん臨床研究のインフォームド・コンセントの指 針，癌の臨床，42，339-352(1996). 